\title{
Increase in $\alpha$-linolenic Acid in Milk Fat by Feeding the Calcium Soap of Fatty Acids Prepared from Linseed Oil
}

\author{
Takamitsu Air, Mitsunori Kurihara and Shuuzou IshidA* \\ Kyushu National Agricultural Experiment Station, \\ Nishigoshi-cho, Kumamoto-ken 861-11 \\ * Research and Development Department, \\ Taiyo Yushi Co., Ltd. Yokohama-shi 221
}

(Received May 31, 1990)

Key words: linseed oil, calcium soap, $\alpha$-linolenic acid, milk fat, dairy cows

In industrialized countries, where much food is affluently supplied, food is required to be an energy source as well as containing essential nutrients for the maintenance of human health. For instance, it has been accepted that the ingestion of vegetable oils containing more poly-unsaturated fatty acids (PUFAs) is better than that of animal fat with poly-saturated fatty acids for human health ${ }^{5,10)}$. Much attention is especially paid to the ingestion of $n-3$ PUFAs such as $\alpha$-linolenic (n-3 linolenic acid, n-3 LA), eicosapentaenoic and docosahexaenoic acids in terms of the reduction of some cardiovascular diseases ${ }^{7,10)}$. According to OKU$\mathrm{YAMA}^{81}$, an insufficiency of $\mathrm{n}-6$ fatty acid intake seems unlikely for the Japanese from their food consumption patterns, but, there is a possibility of a shortage of $n-3$ fatty acid intake. He also reported that the desirable ration of $n-3 L A$ to linoleic acid is about 3 for the maintenance of the health of the Japanese.

On the other hand, it is revealed that milk fatty acid composition can be changed by fecding cows with oils ${ }^{6,11}$. For instance, ScotT et al. ${ }^{11)}$ demonstrated that linolenic acid content in the milk fat was increased from 1.1 to $21.9 \%$ by feeding $1,500 \mathrm{~g}$ of formaldehydetreated-linseed oil to cows. Since most of the PUFAs in oils are hydrogenated in the rumen of cow ${ }^{11}$, the protection of the oils from hydrogenation is needed to incorporate the PUFAs into milk fat. The conversion of the oils to calcium soap is supposed to be a way of protection because calcium soap is insoluble in the rumen.

This paper deals with the degree of increase in $n-3$ LA content in milk fat when the cows were fed the calcium soap of fatty acids prepared from linseed oil rich in n-3 LA,

\section{Materials and Methods}

Feeding experiment

Two Holstein cows each were used in the study for the feeding experiments. The cows received Italian ryegrass haylage and hay ad libitum and a formula feed and beet pulp

アマ二油から調製した脂肪酸カルシウム㙁給与時の乳脂肪中の $\alpha$-リノレン酸の増加：相井孝允・栗原光規・石田 修三（九州農業試験場 熊本県西合志町 861-11) 
equivalent to the nutrient requirement for milk yield throughout the trials. In addition to the above diets, the animals were given calcium soaps prepared from palm, soybean or linseed oils or linseed only, respectively, during the treatment periods. The feeding amounts are shown in Table 1.

The trials consisted of a $2-$ wk non-treatment period followed by a 2 -wk treatment period. But, in the case of the calcuim soap from linseed oil, feedings were done in the order of $0,200,300,400$ and $500 \mathrm{~g}$ per day every $2-w \mathrm{k}$.

The fatty acid composition of palm, soybean and linseed oils are also given in Table 1. The calcium soaps from palm, soybean and linseed oils, which were prepared by Taiyo Yushi Co., Ltd. (Yokohama) using the method reportcd previously $^{3)}$, contained 11.1, 5.6, $13.0 \%$ moisture and $8.4,6.3,6.0 \% \mathrm{Ca}$, respectively. Linseed was purchased from a local merchant.

Milk samples were collected for the last 4 days of every period. Morning and evening milks were combined and analysed for fat, protein and total solids according to our procedure $^{3)}$. The analysis of milk fatty acids was performed as follows: After the solution containing methyl esters of the milk fatty acids were obtained by the procedure described in the previous paper ${ }^{1)}$, it was subjected to a gas-chromatograph (GC) with a flame ionization detector (GC-14 A, Shimadzu) and the chromatograms were recorded on a thermal-pen recorder (Chromatopack C-R 5 A, Shimadzu). A capillary column was used for the analysis: $50 \mathrm{~m}$ long and $0.25 \mathrm{~mm}$ i.d. (WCOT fused silica, CP-Sil 88 from Chrompack, The Netherland). Usually $0.5 \mu l$ of each sample was injected into a GC.

The operating conditions were as follows: column temperature was programmed from 100 to $230^{\circ} \mathrm{C}$ at a rate of $10^{\circ} \mathrm{C} / \mathrm{min}$ and held at $230^{\circ} \mathrm{C}$ for $7 \mathrm{~min}$. ; injection port, $230^{\circ} \mathrm{C}$; detector, $230^{\circ} \mathrm{C} ; \mathrm{H}_{2}, 0.58 \mathrm{~kg} / \mathrm{cm}^{2}$; Air, $0.55 \mathrm{~kg} / \mathrm{cm}^{2}$; $\mathrm{He}, 1.6 \mathrm{~kg} / \mathrm{cm}^{2}$; make up gas, $0.1 \mathrm{~kg} / \mathrm{cm}^{2}$.

The methyl ester of $n-3$ LA was confirmed by comparing retention time with the authentic sample prepared from perilla oil and identified by a gas-chromatograph-mass-spectrometry (QP-1000 A, Shimadzu) with a library research system (LSS-20, Shimadzu).

\section{Results and Discussion}

As shown in Table 1, linseed and soybean oils contained $56 \%$ and $7 \%$ n-3 LA, respectively, but the acid was hardly present in palm oil. In cases of feeding $900 \mathrm{~g}$ linseed containing about $360 \mathrm{~g}$ linseed oil and calcium soap from palm oil, n-3 LA in the milk fat remained almost unaltered compared with that during a nontreatment period. Since linseed is rich in $n-3$ LA, it was assumed that degradation and/or hydrogenation of $n-3 L A$ in the digestive tracts and/or body of cows occurred before $\mathrm{n}-3$ LA was incorporated into milk fat. The hydrogenation of $n-3$ LA was supported by the increase in C $18: 1$ (oleic acid) content in the milk fatty acids. When the cows were fed the calcium soap from soybean oil, n-3 LA in the milk fat showed about a two-fold increase compared with that during a non-treatment period.

Milk fat of the cows under conventional feeding conditions during a non-treatment period contained $0.4-0.5 \% \mathrm{n}-3 \mathrm{LA}$. In case of feeding the calcium soap from linseed oil (CSLO), n-3 LA content in the milk fat increased; the contents were $0.49,0.57,0.86$, 1.40 and $1.94 \%$ in proportion to the feeding amounts of CSLO, 0, 200, 300, 400 and $500 \mathrm{~g}$, respectively. Though n-3 LA content in the milk fat is related to the feeding amount of CSLO, the feeding amount to cows is restricted by the physiological limitation of cows and because of economic reasons.

Milk fat of the cows, which produced $26.6 \mathrm{~kg}$ milk with $3.29 \%$ fat as shown in Table 1 , contained about $16.1 \mathrm{~g} \mathrm{n} 3 \mathrm{~L} \Lambda$, when the cows were fed on each $500 \mathrm{~g}$ of CSLO. And n-3 LA intake per cow was equivalent to $229 \mathrm{~g} /$ day $[500 \mathrm{~g}($ CSLO intake $) \times 0.87(\mathrm{DM} \%) \times 0.94$ 


\section{AII, Kurihara and IsHIDA}

(fatty acids \% in calcium soap) $\times 0.56$ (n-3 LA $\%$ in fatty acids)]. Thus, the transfer coefficient of n-3 LA into milk fat was roughly estimated to be $5 \%$.

On the other hand, the amounts of $\mathrm{C} 18$ (stearic acid) and C $18: 2$ (linoleic acid) showed slight increases when the cows were given CSLO, that of C 18:1 (oleic acid including elaidic acid) increased remarkably, but that of $\mathrm{C} 16$ (palmitic acid) decreased markedly. These facts indicate that a considerable amount of the ingested n-3 LA was hydrogenated to give $C 18: 1$ regardless of the calcium soap being insoluble in the rumen, and that feeding with the oil rich in $n-3$ LA protected from hydrogenation in the digestive tracts and/or from degradation in the body of cows may remarkably increase $n-3$ LA content

Table 1. Fatty acid composition of palm, soybean and linseed oils and milk fat from the

\begin{tabular}{|c|c|c|c|c|c|c|c|}
\hline & \multicolumn{3}{|c|}{ Oil } & & & & \\
\hline & \multirow[t]{2}{*}{ Palm } & \multirow[t]{2}{*}{ Soybean } & \multirow[t]{2}{*}{ Linseed } & \multicolumn{2}{|c|}{ Palm } & \multicolumn{2}{|c|}{ Soybean } \\
\hline & & & & $0^{a}$ & $200^{\circ}$ & $0^{2}$ & $400^{2}$ \\
\hline $\begin{array}{l}\text { Milk yield } \\
(\mathrm{kg})\end{array}$ & & & & 25.0 & 26.0 & 20.2 & 19.7 \\
\hline Milk fat & & & & 3.36 & 3.74 & 3.18 & 3.05 \\
\hline $\begin{array}{l}\text { Total milk } \\
\text { solids }(\%)\end{array}$ & & & & 11.96 & 12.24 & 11.59 & 12.05 \\
\hline \multicolumn{8}{|c|}{$\begin{array}{l}\text { Fatty acid } \\
(\% \text { on the chromatogram) }\end{array}$} \\
\hline $\mathrm{C} 4$ & & & & 2.89 & 2.81 & 2.99 & 3.04 \\
\hline $\mathrm{C} 6$ & & & & 2.34 & 2.24 & 2.38 & 2.34 \\
\hline $\mathrm{C} 8$ & & & & 1.50 & 1.48 & 1.53 & 1.55 \\
\hline $\mathrm{C} 10$ & & & & 3.47 & 3.74 & 3.51 & 3.70 \\
\hline $\mathrm{C} 12$ & & & & 3.89 & 4.00 & 3.88 & 4.01 \\
\hline C14 & 1.02 & & & 11.69 & 11.61 & 11.90 & 11.08 \\
\hline $\mathrm{C} 16$ & 40.08 & 10.43 & 5.26 & 29.72 & 27.92 & 29.62 & 24.30 \\
\hline $\mathrm{C} 18$ & 5.29 & 4.62 & 3.06 & 8.34 & 10.78 & 9.37 & 10.17 \\
\hline $\mathrm{C} 12: 1$ & & & & 0.05 & 0.03 & 0.04 & 0.02 \\
\hline $\mathrm{C} 14: 1$ & & & & 0.33 & 0.22 & 0.32 & 0.31 \\
\hline $\mathrm{C} 16: 1$ & & & & 0.81 & 0.79 & 0.55 & 0.49 \\
\hline $\mathrm{C} 18: 1$ & 39.69 & 23.04 & 18.92 & 21.23 & 20.13 & 18.37 & $\begin{array}{r}(9.31) \\
13.79\end{array}$ \\
\hline $\mathrm{C} 18: 2$ & 8.75 & 50.62 & 14.42 & 2.45 & 3.51 & 2.19 & 2.74 \\
\hline $\mathrm{C18}: 3^{\mathrm{c}}$ & 0.04 & 7.01 & 56.00 & 0.47 & 0.35 & 0.39 & 0.82 \\
\hline minors & 5.13 & 4.28 & 2.34 & 10.82 & 10.39 & 12.96 & 12.33 \\
\hline Ratio & 0.00 & 0.14 & 3.88 & 0.19 & 0.10 & 0.18 & 0.30 \\
\hline
\end{tabular}

: A figure denotes the amount of calcium soap of fatty acids fed to the cow $(\mathrm{g})$.

: A figure denotes the amount of linseed fed to the cow (g).

c: C 18:3 shows a-linolenic acid only.

¿: Ratio of C $18: 3$ to C $18: 2$

A figure in the parenthesis denotes elaidic acid (trans-oleic acid) $\%$. 
in milk fat.

Linolenic acid content in the milk fat of cows under conventional conditions was reported to range within 0.76 to $2.07 \% 1,2,4,9,11-13$ ) depending on the stage of lactation ${ }^{12)}$. The levels were considerably higher compared with that in this report. The reason is probably as follows: by a capillary column method, $\gamma$ linolenic acid ( $\mathrm{n}-6$ linolenic acid, n-6 LA) was not found in fatty acids from the milk fat, but two relatively small peaks, one of which was tentatively identified as $\mathrm{C} 20$ (eicosanoic acid), were detected near the peak of n-3 LA peak on the chromatogram. Since these three peaks including that of $n-3$ LA could not be separated on a packed column, the value of linolenic acid reported in most published papers ${ }^{4,9,11-133}$ including our papers ${ }^{1,2)}$ appears to be the sum of

cows received the calcium soap of fatty acids prepared from palm, soybean and linseed oils

\begin{tabular}{|c|c|c|c|c|c|c|}
\hline \multicolumn{5}{|c|}{ Calcium soap } & \multicolumn{2}{|c|}{ Linseed } \\
\hline \multicolumn{5}{|c|}{ Linseed } & \multirow[b]{2}{*}{$0^{\mathrm{b}}$} & \multirow[b]{2}{*}{$900^{\mathrm{b}}$} \\
\hline $0^{a}$ & $200^{\mathrm{a}}$ & $300^{\mathrm{a}}$ & $400^{\circ}$ & $500^{\mathrm{a}}$ & & \\
\hline 26.0 & 27.2 & 29.0 & 26.4 & 26.6 & 20.5 & 22.4 \\
\hline 3.01 & 2.98 & 3.19 & 3.12 & 3.29 & 3.75 & 3.65 \\
\hline 10.95 & 10.92 & 10.96 & 10.92 & 11.04 & 12.83 & 12.56 \\
\hline 2.98 & 2.80 & 3.07 & 3.13 & 2.99 & 3.17 & 3.25 \\
\hline 2.49 & 2.17 & 2.27 & 2.25 & 2.01 & 2.48 & 2.43 \\
\hline 1.63 & 1.35 & 1.37 & 1.31 & 1.16 & 1.56 & 1.50 \\
\hline 3.97 & 3.08 & 2.96 & 2.74 & 2.39 & 3.72 & 3.30 \\
\hline 4.45 & 3.42 & 3.15 & 2.83 & 2.51 & 4.13 & 3.62 \\
\hline 13.40 & 11.68 & 11.19 & 10.37 & 9.67 & 12.78 & 11.02 \\
\hline 30.97 & 26.80 & 25.83 & 24.07 & 22.27 & 37.60 & 30.15 \\
\hline 9.26 & 10.46 & 11.76 & 11.89 & 11.94 & 6.54 & 11.40 \\
\hline 0.04 & 0.04 & 0.04 & 0.04 & 0.04 & 0.03 & 0.03 \\
\hline 0.36 & 0.36 & 0.32 & 0.49 & 0.31 & 0.53 & 0.51 \\
\hline 0.59 & 0.65 & 0.59 & 0.51 & 0.60 & 0.37 & 0.36 \\
\hline \multirow[t]{2}{*}{17.37} & 22.22 & 23.54 & $(8.19)$ & $(13.01)$ & 14.95 & 21.72 \\
\hline & & & 17.44 & 15.25 & & \\
\hline 1.57 & 1.89 & 1.88 & 1.73 & 1.74 & 1.54 & 1.54 \\
\hline 0.49 & 0.57 & 0.86 & 1. 40 & 1.94 & 0.40 & 0.47 \\
\hline 10.43 & 12.51 & 11.17 & 11.61 & 12.17 & 10.20 & 8.70 \\
\hline 0.31 & 0.30 & 0.46 & 0.81 & 1.11 & 0.26 & 0.31 \\
\hline
\end{tabular}




\section{AII, KURIHARA and ISHIDA}

the three acids above.

As shown in Table 1, the ratio obtained by feeding of $500 \mathrm{~g}$ of CSLO was 1.1 , but it was considerably narrower than the ratio recomended by OKUYAMA ${ }^{8)}$ in terms of health of the Japanese. The technique for broadening the ratio will be required in the future.

\section{Acknowledgements}

We are grateful to Dr. H. TANAKA (National Institute of Animal Industry) for his helpful suggestions and observations and his critical reading of the manuscript.

\section{References}

1) Ari, T., S. Takahashi, M. Kurihara and S. KUME, Fatty acid composition of milk during a hot summer. Jpn. J, Zootech. Sci., 59: 278-284. 1988.

2) AiI, T., S. Takahashi,, M. Kurihara and S. KUME, The effects of Italian ryegrass hay, haylage and fresh Italian ryegrass on the fatty acid composition of cows' milk. Jpn. J. Zootech. Sci., 59: 718-724. 1988.

3) AlI, T., M. Kurihara, S. Kume, M. Tomita and H. HAYASAWA, Effect of supplementing calcium soap of fatty acids and sodium acetate to dairy cows on milk yield, milk composition and milk fatty acid composition. Jpn. J. Zootech. Sci., 61 : 931-936. 1990.

4) Brown, W.H., J.W. Stull and G.H. Stort, Fatty acid composition of milk. I. Effect of roughage and dietary fat. J. Dairy Sci.,
45 : 191-196. 1962.

5) Consensus Conference, Lowering blood cholesterol to prevent heart disease. J. Am. Med. Assoc., 253 : 2080-2086. 1985.

6) Hagemeister, H., D. Precht and C.A. BARTH, Studies on transfer of omega-3 fatty acids into bovine milk fat. Milchwissenschaft, 43: 153-158. 1988.

7) Herold, M.P. and J.E. Kinselda, Fish oil consumption and decreased risk of cardiovascular disease: a comparison of findings from animal and human feeding trials. Am. J. Clin. Nutr., 43:566-598. 1986.

8) Okuyama, H., Nutritional biochemistry of essential fatty acids. Seibutsu to Kagaku, 28 : 175-181. 1990.

9) Rambo, R.S., G.W. Reinbold and W.S. Clark, Jr., Fatty acid composition of milk. I. Some differences in common dairy breeds. J. Dairy Sci., 47 : 1412-1414. 1964.

10) Simoroulos, P.A., Summary of the conference on the health effects of polyunsaturated fatty acids in seafoods. J. Nutr., 116. 2350-2354. 1986.

11) Scott, T.W., L.J. Cook, K.A. FERguson and I.W. McDonald, Production of polyunsaturated milk fat in domestic ruminants, Aust. J. Sci., 32: 291-293. 1970.

12) Stull, J.W., W.H. Brown, C. Valdez and H. TUCKER, Fatty acid composition of milk. II. Variation with stage of lactation. J. Dairy Sci, 49 : 1401-1405. 1966.

13) Tsugou, T. and K. Yamauchi, Gyuunyuu no Kagaku. 33-37. Chikyusha. Tokyo. 1975. 